\title{
Effects of Temperature at Different Growth Stages on Nonstructural Carbohydrate, Nitrate Reductase Activity and Yield of Potato
}

\author{
Subhash Chandra GHosh, Koh-ichiro Asanuma, Akihito Kusutani and Masanori Toyota \\ Faculty of Agriculture, Kagawa University, Miki-cho, Kagawa 761-0795, Japan
}

(Received February 24, 2000)

\begin{abstract}
The effect of temperature $\left(15,25,30^{\circ} \mathrm{C}\right.$ and glasshouse as control) at different growth stages (stage-I : vegetative to tuber initiation, stage-II : tuber initiation to initial tuber bulking and stage-III : tuber bulking to maturity) on leaf nitrate reductase (NR) activity, carbohydrate contents and tuber yield were investigated in potatoes (Solanum tuberosum L. cvs. May Queen and Norin 1) as pot experiment in naturally lit glasshouse and phytotron. The high temperature treatment decreased the total dry matter production as well as tuber yield and degraded the tuber quality by reducing the specific gravity. NR activity of leaves was also decreased by high temperature treatment, whereas low temperature increased the activity. Water soluble carbohydrate (WSC) and starch content in leaves were sequentially decreased and as a result total nonstructural carbohydrates (TNC) were also decreased by high temperature. The inhibition of tuber yield by high temperature was due to the limited translocation of carbohydrates from leaves to the tubers, following the reduction of NR activity and the expense of carbohydrates for dark respiration. The maximum yield reduction was observed at high temperature treatment at stage-I which was most critical for tuber yield, and low temperature at stage-II produced the highest yield which was considered as more advantageous step towards yield improvement.
\end{abstract}

Keywords : growth stages, potato (Solanum tuberosum L.), specific gravity, temperature, tuber yield

\section{INTRODUCTION}

The major constraints for potato plant growth and tuber yields are environmental stress conditions. Environmental factors such as temperature, moisture, light and fertilizer play key roles in the variation of plant growth and tuber yield. Potatoes are grown all over the world from tropics to cool area. The yield of potato in the warm tropics is limited by high temperatures (Borah and Milthorpe, 1962; Awan, 1964), but there is considerable variation in field production in warm climates (Ewing, 1981). Moreover, the large temperature perturbations above and below normal during the growing season can cause relatively undetermined effects on the growing potato plants. The potential for damage from these temperature variations depends on the stage of crop developments which they occur. There are some reports about the high temperature stress on potato growth and yield (Bodlaender, 1963; Gregory, 1965 ; Marinus and Bodlaender, 1975 ; Levy, 1986), but none of them considered the

Corresponding author : Koh-ichiro Asanuma, e-mail : asa@ag.kagawa-u.ac.jp 
growth stages critical for tuber yield.

On the other hand, nitrate is the principal form of nitrogen absorbed by plants. However, it can be used in amino acid for protein synthesis, so it must be reduced to ammonia form. The first step in this reduction process is conversion of nitrate to nitrite by the nitrate reductase (NR) enzyme. Supra-optimal temperatures and moisture deficits result in a relatively rapid decrease or inactivation of NR activity in plants (Mattas and Pauli, 1965 ; Younis et al., 1965 ; Schrader et al., 1968). NR seems to be unique among the other enzymes being inactivated by heat stress employed (Onwueme et al., 1971).

It is well known that the carbohydrate synthesis and translocation are affected by temperature (Wolf et al., 1990). In potato plants, there are some reports concerning high temperature effects on carbohydrate metabolism, suggesting the reduction of carbohydrate synthesis and translocation from source leaf to the tubers and reduced the yield (Borah and Milthorpe, 1962 ; Krauss and Marschner, 1984; Mohabir and John, 1988 ; Lafta and Lorenzen, 1995).

Even in natural conditions, temperature fluctuation sometimes observed in the potato growing areas which may be happened in the different growth stages during the growing season and can influenced the growth and yield of potato. For that we admixed different temperature treatments at different growth stages.

Considering the above, we conducted the present experiment in order to evaluate the role of different temperature treatments at different growth stages on dry matter production, leaf NR activity and carbohydrate contents in relation to tuber yield and quality, and also to find out the severity of treatments which is more detrimental for tuber yield.

\section{MATERIALS AND METHODS}

The experiment was conducted in clay pots $(30 \mathrm{~cm}$ in diameter and $24 \mathrm{~cm}$ in depth) in naturally lit glasshouse and temperature controlled phytotron (Shimadzu, Japan, Model SCN-181) in March 1999. The experimental conditions of different treatments and atmospheric temperature (inside glasshouse temperature varied $1-3^{\circ} \mathrm{C}$ above depending on weather conditions) at different growth stages are presented in Fig. 1 and Table 1. Each pot was filled with coarse sandy loam soil equivalent to $9.0 \mathrm{~kg}$ of dry weight. The field capacity of the soil determined by gravimetric methods was $29.8 \%$. The soil moisture content at $80 \%$ field capacity was considered to the optimum for standard growth of the potato plants (Petr et al., 1988) and maintained throughout the season by regular weighing the pot and adding water at 8: 00 A.M. According to the fertilizer recommendation based on soil analysis $5.0 \mathrm{~g}$ ammonium sulfate, $6.0 \mathrm{~g}$ superphosphate and $2.0 \mathrm{~g}$ potassium chloride were mixed into the soil prior to seed tuber planting. About $50 \mathrm{~g}$ seed tubers were planted in the pots and after germination two stems were kept finally to be grown. Plants were grown in glasshouse and different temperature treatments $\left(15,25,30^{\circ} \mathrm{C}\right)$ were imposed starting $10 \mathrm{~d}$ after germination in the phytotron at three growth stages (stage-I : vegetative to tuber initiation, stage-II : tuber initiation to initial tuber bulking, stage-III : tuber bulking to maturity). Duration of each treatment was $20 \mathrm{~d}$. Two potato cultivars May Queen and Norin 1 different in their growth habit (leafy and stemmy type) were used. There were three replications and the pots were arranged in a randomized block design and each pot was considered as one replication. Plants were sampled at the end of each treatment. Three pots per treatment were sampled and plants were separated into stems, leaf blades, petioles, stolons, tubers and roots. Measurements included the length of the main stem, leaf area, stolon number, tuber number, fresh and dry weight of each organ. For yield determination, three pots per treatment were harvested, and total yield, yield components and dry weight of tubers were recorded. At final harvest, the specific gravity of tuber was measured by the weight in air and in water. 
Table 1 Experimental conditions of different treatments and atmospheric temperature (inside GH temperature range $2-3^{\circ} \mathrm{C}$ above during the daytime) and average relative humidity at different growth stages.

\begin{tabular}{|c|c|c|c|c|c|c|c|c|}
\hline \multirow{3}{*}{ Growth stages } & \multirow{3}{*}{ Treatments } & \multicolumn{3}{|c|}{ Treatment duration } & \multicolumn{4}{|c|}{$\begin{array}{c}\text { Atmospheric temperature and relative } \\
\text { humidity (stage average) }\end{array}$} \\
\hline & & \multirow[t]{2}{*}{$20(d)$} & \multirow[t]{2}{*}{$20(d)$} & \multirow[t]{2}{*}{$20(d)$} & \multicolumn{3}{|c|}{ Temperature $\left({ }^{\circ} \mathrm{C}\right)$} & \multirow{2}{*}{$\begin{array}{c}\text { Relative } \\
\text { humidity (\%) }\end{array}$} \\
\hline & & & & & Min. & Max. & Av. & \\
\hline & Control (GH) & GH & GH & GH & & & & \\
\hline \multirow{3}{*}{$\begin{array}{l}\text { Stage-I } \\
\text { (Apr. 12-May 1) }\end{array}$} & $15^{\circ} \mathrm{C}$ (stage-I) & $15^{\circ} \mathrm{C}$ & GH & GH & 9.80 & 19.87 & 14.33 & 60.12 \\
\hline & $25^{\circ} \mathrm{C}$ (stage-I) & $25^{\circ} \mathrm{C}$ & GH & GH & & & & \\
\hline & $30^{\circ} \mathrm{C}$ (stage-I) & $30^{\circ} \mathrm{C}$ & GH & GH & & & & \\
\hline \multirow{3}{*}{$\begin{array}{l}\text { Stage-II } \\
\text { (May 2-May 21) }\end{array}$} & $15^{\circ} \mathrm{C}$ (stage-II) & GH & $15^{\circ} \mathrm{C}$ & GH & 13.05 & 25.91 & 19.36 & 61.32 \\
\hline & $25^{\circ} \mathrm{C}$ (stage-II) & GH & $25^{\circ} \mathrm{C}$ & GH & & & & \\
\hline & $30^{\circ} \mathrm{C}$ (stage-II) & $\mathrm{GH}$ & $30^{\circ} \mathrm{C}$ & GH & & & & \\
\hline \multirow{3}{*}{$\begin{array}{l}\text { Stage-III } \\
\text { (May 22-Jun. 10) }\end{array}$} & $15^{\circ} \mathrm{C}$ (stage-III) & GH & GH & $15^{\circ} \mathrm{C}$ & 15.64 & 25.62 & 20.55 & 71.31 \\
\hline & $25^{\circ} \mathrm{C}$ (stage-III) & GH & GH & $25^{\circ} \mathrm{C}$ & & & & \\
\hline & $30^{\circ} \mathrm{C}$ (stage-III) & GH & $\mathrm{GH}$ & $30^{\circ} \mathrm{C}$ & & & & \\
\hline
\end{tabular}

Stage-I : vegetative to tuber initiation, stage-II : tuber initiation to initial tuber bulking, stage-III : tuber bulking to maturity. GH, glasshouse.

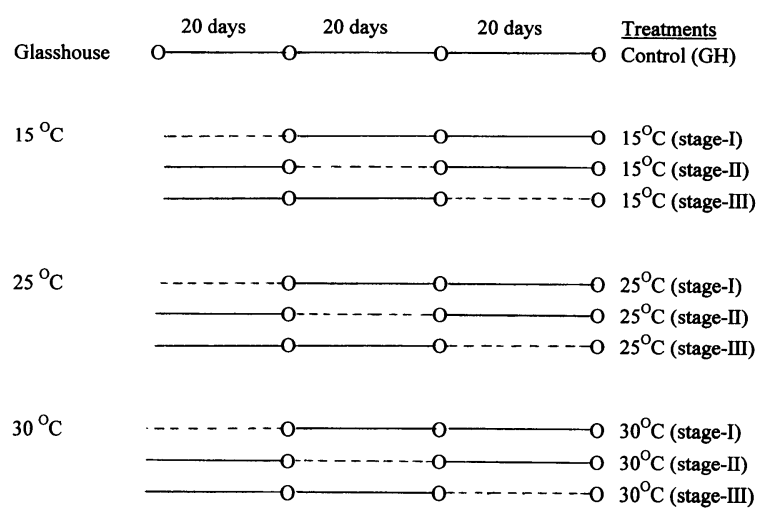

Fig. 1 Schematic diagram of different temperature treatments.

Solid line indicates $\mathrm{GH}$ and broken line indicates temperature treatments in phytotron. $\mathrm{O}$, sampling.

NR activity was determined every $10 \mathrm{~d}$ after treatment following in vivo NR assay as described by Kapoor and Li (1982). Fully expanded leaf (third and fourth leaves from the apex) samples were composited (five replicates) and analysis was done in triplicate at three growth stages.

The concentration of carbohydrate was determined from leaf blades at the end of each treatment period at three stages of growth. For water soluble carbohydrate (WSC), $0.1 \mathrm{~g}$ dried samples were extracted once with ethanol $(80 \%)$ at $60^{\circ} \mathrm{C}$ and twice with distilled water at $70^{\circ} \mathrm{C}$. WSC was measured by anthrone method (Yemm and Willis, 1954). The residue was used for starch determination after suspended in distilled water and heated at $120^{\circ} \mathrm{C}$ for 10 min within an autoclave for gelatinization. After cooling, $\alpha$-amylase (Wako Pure Chemical 

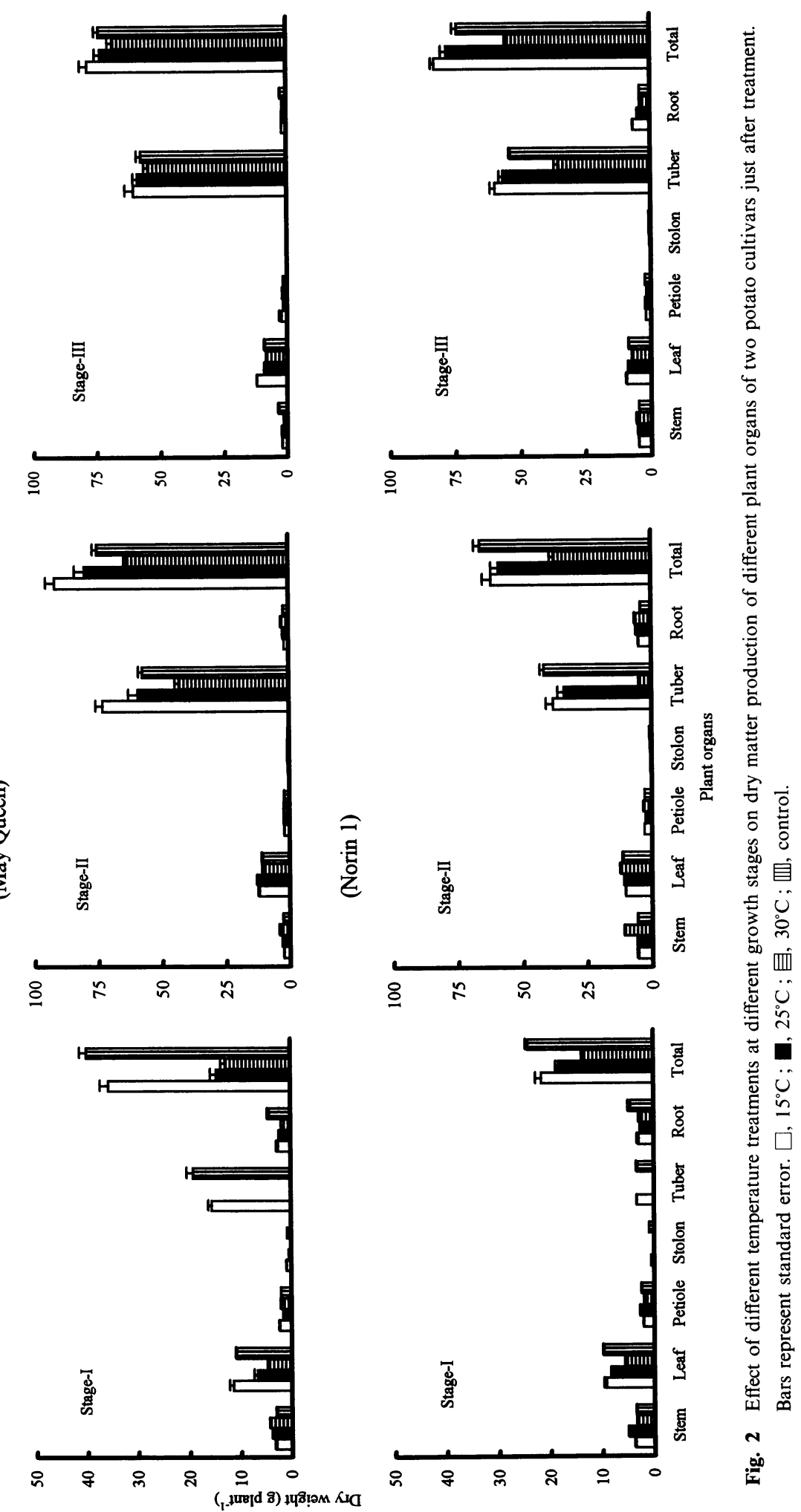
Industries Ltd., Japan) with phosphate buffer (pH 5.8) was added to the residue and it was incubated for $16 \mathrm{~h}$ at $40^{\circ} \mathrm{C}$ in shaking bath for breakdown of starch. Starch concentration was determined from glucose standard by anthrone method. The sum of WSC and starch was considered as total nonstructural carbohydrate (TNC).

All statistical analyses were performed by software MSTAT package (Michigan State University, USA).

\section{RESULTS}

\section{Dry matter production}

Dry weights of each organ just after the treatment are shown in Fig. 2. In all growth stages, the total dry matter production was decreased with increasing temperature in both cultivars. This response was due to the decrease in tuber weight with a relatively small response in leaf and stem weight. In stage-I, glasshouse treated (control) plant produced the highest amount of total dry matter followed by 15,25 and $30^{\circ} \mathrm{C}$ treated plants in both cultivars. In stage-II, high temperature decreased the total dry matter in both cultivars, but it increased stem and leaf dry matter. In May Queen, $15^{\circ} \mathrm{C}$ treated plant produced the maximum amount of total and tuber dry matter followed by $25^{\circ} \mathrm{C}$ treated plant. In Norin 1, control plant produced the maximum amount of total and tuber dry matter followed by $15^{\circ} \mathrm{C}$ treated plant. In stage-III, trend in dry matter production was similar in both cultivars and plant treated with $15^{\circ} \mathrm{C}$ produced the highest amount of total and tuber dry matter. Among all the growth stages, decrease in dry matter production by higher temperature was maximum in stage-I in both cultivars which were 68 and $43 \%$ in May Queen and Norin 1 respectively over control.

\section{Nitrate reductase activity}

Table 2 shows the effect of different temperature at different growth stages on NR activity at 10 and $20 \mathrm{~d}$ from the beginning of treatment. Higher temperature treatment almost decreased the NR activity at all growth stages. In stage-I, $15^{\circ} \mathrm{C}$ treated plants in both cultivars showed the higher NR activity. Whereas, $25^{\circ} \mathrm{C}$ treated plant showed the lowest NR activity at $10 \mathrm{~d}$ in both cultivars. In stage-II, $15^{\circ} \mathrm{C}$ treated plants showed the highest NR activity followed by control, 25 and $30^{\circ} \mathrm{C}$ treated plants. In stage-III, the NR activity showed

Table 2 Effect of different temperature at different growth stages on nitrate reductase $\left(\mu \mathrm{mol} \mathrm{NO}_{2} \mathrm{~g}\right.$ fresh wt. ${ }^{-1} \mathrm{~h}^{-1}$ ) activity of two potato cultivars.

\begin{tabular}{|c|c|c|c|c|c|c|c|}
\hline \multirow{3}{*}{ Cultivar } & \multirow{3}{*}{ Treatment } & \multicolumn{6}{|c|}{ Growth stages } \\
\hline & & \multicolumn{2}{|c|}{ Stage-I } & \multicolumn{2}{|c|}{ Stage-II } & \multicolumn{2}{|c|}{ Stage-III } \\
\hline & & $10^{z}$ & 20 & 10 & 20 & 10 & 20 \\
\hline & $15^{\circ} \mathrm{C}$ & 6.65 & 8.03 & 7.23 & 6.79 & 3.66 & 3.56 \\
\hline & $25^{\circ} \mathrm{C}$ & 3.47 & 6.04 & 2.81 & 3.20 & 3.39 & 3.26 \\
\hline \multirow[t]{2}{*}{ May Queen } & $30^{\circ} \mathrm{C}$ & 4.85 & 3.09 & 2.68 & 2.70 & 2.75 & 2.54 \\
\hline & $\mathrm{GH}$ & 4.03 & 4.39 & 6.36 & 6.12 & 5.63 & 4.12 \\
\hline \multirow[t]{3}{*}{ LSD (0.05) } & & 0.519 & 0.265 & 0.501 & 0.311 & 0.329 & 0.131 \\
\hline & $15^{\circ} \mathrm{C}$ & 3.43 & 5.04 & 8.00 & 5.50 & 5.89 & 4.26 \\
\hline & $25^{\circ} \mathrm{C}$ & 2.22 & 3.06 & 5.72 & 4.47 & 4.20 & 4.71 \\
\hline \multirow[t]{2}{*}{ Norin 1} & $30^{\circ} \mathrm{C}$ & 3.41 & 2.88 & 3.86 & 2.29 & 3.58 & 3.72 \\
\hline & $\mathrm{GH}$ & 3.84 & 3.93 & 7.40 & 5.64 & 5.20 & 4.38 \\
\hline LSD (0.05) & & 0.366 & 0.195 & 0.368 & 0.579 & 0.138 & 0.512 \\
\hline
\end{tabular}

${ }^{z}$ Days from the beginning of treatments. 
Table 3 Effect of different temperature at different growth stages on water soluble carbohydrates (WSC), starch and total nonstructural carbohydrates (TNC) of leaves just after treatment of two potato cultivars.

\begin{tabular}{|c|c|c|c|c|c|c|c|c|c|c|}
\hline \multirow{2}{*}{ Cultivar } & \multirow{2}{*}{$\begin{array}{l}\text { Temperature } \\
\text { regimes }\end{array}$} & \multicolumn{3}{|c|}{ Stage-I } & \multicolumn{3}{|c|}{ Stage-II } & \multicolumn{3}{|c|}{ Stage-III } \\
\hline & & WSC & Starch & TNC & WSC & Starch & TNC & WSC & Starch & TNC \\
\hline \multirow{4}{*}{ May Queen } & $15^{\circ} \mathrm{C}$ & 6.63 & 4.46 & 11.09 & 16.49 & 8.72 & 25.21 & 15.68 & 3.92 & 19.60 \\
\hline & $25^{\circ} \mathrm{C}$ & 6.09 & 4.36 & 10.45 & 10.38 & 8.42 & 18.8 & 13.90 & 5.76 & 18.66 \\
\hline & $30^{\circ} \mathrm{C}$ & 5.31 & 2.73 & 8.04 & 7.57 & 3.49 & 11.06 & 6.68 & 3.15 & 9.83 \\
\hline & $\mathrm{GH}$ & 8.35 & 5.03 & 13.38 & 9.88 & 4.46 & 14.34 & 5.69 & 5.55 & 11.24 \\
\hline $\operatorname{LSD}(0.05)$ & & 0.396 & 0.480 & 0.367 & 0.898 & 0.346 & 1.033 & 0.339 & 0.348 & 0.632 \\
\hline \multirow{4}{*}{ Norin 1} & $15^{\circ} \mathrm{C}$ & 7.73 & 3.06 & 10.79 & 9.72 & 2.53 & 12.25 & 14.77 & 2.91 & 17.68 \\
\hline & $25^{\circ} \mathrm{C}$ & 7.07 & 2.93 & 10.00 & 8.86 & 1.72 & 10.58 & 8.46 & 2.10 & 10.56 \\
\hline & $30^{\circ} \mathrm{C}$ & 5.03 & 0.94 & 5.97 & 7.60 & 1.68 & 9.28 & 9.49 & 2.05 & 11.54 \\
\hline & $\mathrm{GH}$ & 10.26 & 3.45 & 13.71 & 8.46 & 1.93 & 10.39 & 10.22 & 3.66 & 13.88 \\
\hline LSD $(0.05)$ & & 0.316 & 0.202 & 0.444 & 0.256 & 0.177 & 0.319 & 0.273 & 0.133 & 0.329 \\
\hline
\end{tabular}

All the values are in percentage of the dry weight.

variability depending on different treatments. In May Queen, the highest activity was observed in control plants followed by 15,25 and $30^{\circ} \mathrm{C}$ treated plants. Whereas, in Norin 1 , the highest activity was observed in $15^{\circ} \mathrm{C}$ treated plants followed by control, 25 and $30^{\circ} \mathrm{C}$ treated plants. However, on total average $17 \%$ activity was increased by $15^{\circ} \mathrm{C}$ treatment in May Queen and 6\% in Norin 1 over control. Whereas, in case of $30^{\circ} \mathrm{C}$ treatment, 39 and $35 \%$ activity was decreased in May Queen and Norin 1, respectively.

\section{Leaf carbohydrate concentration}

The effect of temperature on carbohydrate contents of two cultivars having variation in the levels of soluble sugars and starch are shown in Table 3. The WSC concentration was almost higher in Norin 1 than that of May Queen. On the other hand, starch content was higher in May Queen than Norin 1. In all the growth stages, the WSC, starch and TNC levels were decreased with increasing temperature in both cultivars. In stage-I, control plant posses the higher concentration of WSC, starch and TNC followed by 15,25 and $30^{\circ} \mathrm{C}$ plants in both culivars. But in stage-II and stage-III, $15^{\circ} \mathrm{C}$ treated plant posses the higher content of WSC, starch and TNC in both cultivars.

\section{Yield characters}

Table 4 shows the effect of different temperature on yield and yield components at final harvest. Tuber number and yield were markedly influenced by different temperature treatment in all the three stages of growth. High temperature treatment $\left(30^{\circ} \mathrm{C}\right)$ at stage-I decreased the tuber number maximum than the other stage of growth. Similarly, high temperature treatment at all growth stages decreased the average tuber weight. High temperature treatment at stage-I decreased yield more than the other stages of growth and yield reduction was higher in Norin 1, than May Queen. But in stage-II, low temperature $\left(15^{\circ} \mathrm{C}\right)$ treated plant produced the maximum tuber yield in both cultivars, and $30^{\circ} \mathrm{C}$ treated plant produced the minimum tuber yield. In stage-III, temperature effect was relatively lower than the other stages, though dry tuber yield reduction was observed in higher temperature treated plant. Tuber specific gravity markedly influenced by the different temperature treatments. Higher temperature treatments sequentially decreased specific gravity of tubers at all stages of growth in both cultivars. But the effect of high temperature was more pronounced at last stage of growth. However, cool temperature $\left(15^{\circ} \mathrm{C}\right)$ treatment increased the specific gravity of tubers 


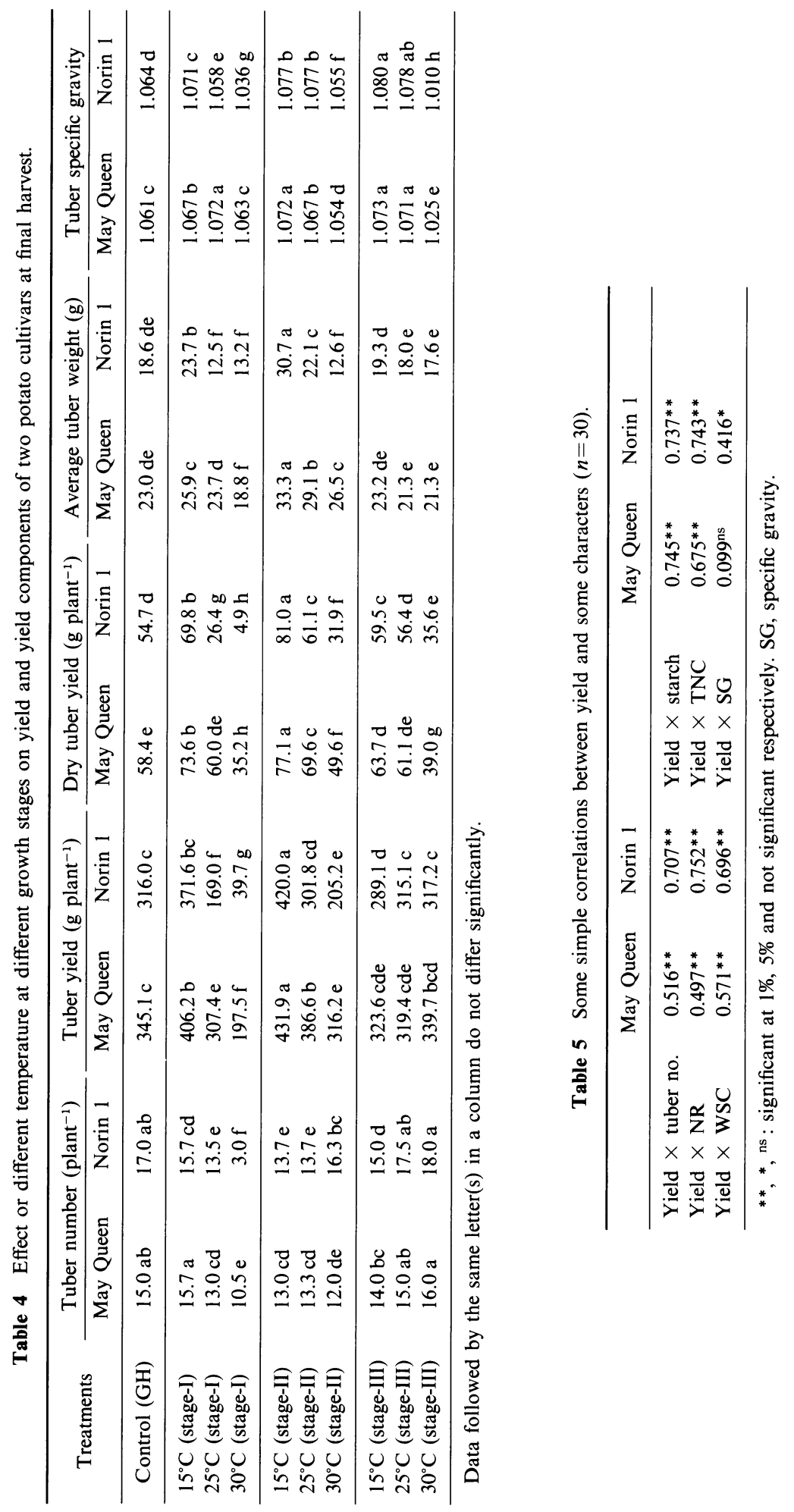


at all stages of growth. The control plants also showed medium specific gravity. The tubers of Norin 1 possessed the higher specific gravity than that of May Queen.

Correlation coefficient between yield and some characters are shown in Table 5. Tuber number showed significant positive correlation with yield in both cultivars. Leaf NR activity, WSC, starch and TNC also maintained significant correlation with yield in both cultivars. Specific gravity of tubers also showed significant correlations with yield in Norin 1, but in May Queen the relation was not significant.

\section{DISCUSSION}

The high temperature $\left(30^{\circ} \mathrm{C}\right)$ treated plant significantly decreased the total dry matter production at all stages of growth. The effect was more pronounced on tuber than that of leaves and stems dry matter. The major constraints to high temperature treated plants were to completely inhibited the tuber initiation at stage-I, at stage-II decrease the dry matter partitioning to tuber and stage-III greatly decreased the tuber specific gravity. Whereas, low temperature treated plants were favored by tuber initiation and higher dry matter production. Treatment duration was $20 \mathrm{~d}$ at different stages of growth and remaining part of growing season the plant were grown in the naturally lit glasshouse. But those $20 \mathrm{~d}$ different temperature treatment at three growth stages affected the whole plant growth, dry matter production and tuber yield. There was little difference between the result immediately after temperature treatment and that of the final harvest in terms of tuber yield. Because plant growth pattern was altered by different temperature treatment at different growth stages. High temperature treatment at early growth stages completely inhibited the tuber initiation in both cultivars. Whereas, low temperature and glasshouse treated plants were favored by tuber initiation. And the yield reduction was maximum in high temperature treatment $\left(30^{\circ} \mathrm{C}\right.$ stage-I $)$ in this stage might be due to the lower tuber number and average tuber weight. At the same time, low temperature treatment in stage-II $\left(15^{\circ} \mathrm{C}\right.$ stage-II $)$ produced the highest yield in both cultivars than other stage of treatments. The possible reason is due to the higher synthesis and translocation of carbohydrates from source leaves to tuber sink as increased demand of tuber and higher plant growth (Moorby, 1968).

Actually cultivars used in this experiment were not tolerant to high temperature treatments. Both cultivars failed to form tuber at high temperature. And the tuber yield markedly decreased by high temperature treatment. But the tuber yield decreased relatively higher in Norin 1 than that of May Queen. Tuber number also decreased drastically in stage-I at $30^{\circ} \mathrm{C}$ treated plant in both cultivars than the other stages of growth. The average tuber weight decreased by high temperature treatments in both cultivars at all stages of growth.

The observed NR inactivation during heat stress could reflect a failure of continued enzyme production during stress. Heat stress resulted in growth retardation as well as NR inactivation and an association between the two effects was considered. The reduction in NR levels were directly related to decreased growth subsequent to heat stress. High temperature treated stress plants were significantly smaller in weight than unstressed and low temperature $\left(15^{\circ} \mathrm{C}\right)$ treated plant. This indicates a similar degree of growth retardation suggesting that the heat inactivation of NR activity may be directly implicated in the growth retardation. As NR activity showed highly significant positive correlation with yield, so yield reduction may be related to the NR activity retardation (Deckard et al., 1973).

The tuber quality is generally judged by the specific gravity of the tubers. Higher specific gravity of tuber is required for higher cooking quality of the potato processing industry. High temperature treatment deteriorated the quality of tuber by decreasing the specific gravity, whereas low temperature treatment increased the specific gravity. The specific gravity of tuber 
was relatively higher in Norin 1 than that of May Queen and Norin 1 showed significant correlation with yield.

Among the kinds of carbohydrate tested in this experiments, WSC is the most sensitive to heat stress. WSC was higher in Norin 1 consequently starch content was higher in May Queen. According to this hypothesis, Norin 1 is more tolerant to heat stress than May Queen. Furthermore, starch accumulation seems to help the heat susceptible genotypes to withstand the conditions of stress. When starch is depleted in the leaves due to midday depression of photosynthesis (Manhas and Sukumaran, 1988), increase in the rate of photorespiration (Ku et al., 1977) or a gradual increase in dark respiration together with an increase in temperature (Winkler, 1971), plant may not withstand heat stress well.

Our observations in this experiment suggested that, inhibition in growth and yield of potato by high temperature was due to reduction in dry matter production as carbohydrate synthesis and translocation limited by heat stress, following the reduction of NR activity and the expense of carbohydrates for dark respiration.

According to the severity of the treatments, the high temperature at stage-I was found to be most critical for tuber yield in both cultivars than that of other stages of growth. Furthermore, the low temperature treatment $\left(15^{\circ} \mathrm{C}\right)$ at stage-II produced the highest tuber yield in both cultivars, which was considered as more advantageous step towards the improvement of yield.

\section{REFERENCES}

Awan, A. B. 1964. Influence of mulch on soil moisture, soil temperature and yield of potatoes. Am. Potato J. 41 : 337-339.

Bodlaender, K. B. A. 1963. Influence of temperature, radiation and photoperiod on development and yield. The growth of potato. Proc. 10th Easter School Agric. Sci., Univ. Nottingham 1963 : 199210.

Borah, M. N., Milthorpe, F. L. 1962. Growth of the potato as influenced by temperature. Indian J. Plant Physiol. 5: 53-72.

Deckard, E. L., Lambert, R. J., Hageman, R. H. 1973. Nitrate reductase activity in corn leaves as related to yields of grain and grain protein. Crop Sci. $13: 343-350$.

Ewing, E. E. 1981. Heat stress and the tuberization stimulus. Am. Potato J. 58 : 31-49.

Gregory, L. E. 1965. Physiology of tuberization in plants (tubers and tuberous roots). Encycl. Plant Physiol. 15 : 1328-1354.

Kapoor, A. C., Li, P. H. 1982. Effects of age and variety on nitrate reductase and nitrogen fraction in potato plants. J. Sci. Food Agric. 33: 401-406.

Krauss, A., Marschner, H. 1984. Growth rate and carbohydrate metabolism of tubers exposed to high temperatures. Potato Res. $27: 297-303$.

Ku, S. B., Edwards, G. E., Tanner, C. B. 1977. Effect of light, carbon dioxide, and temperature on photosynthesis, oxygen inhibition of photosynthesis and transpiration in Solanum tuberosum. Plant Physiol. 59: 868-872.

Lafta, A. M., Lorenzen, J. H. 1995. Effect of high temperature on plant growth and carbohydrate metabolism in potato. Plant Physiol. 109 : 637-643.

Levy, D. 1986. Tuber yield and tuber quality of several potato cultivars as affected by seasonal high temperatures and by water deficit in a semiarid environment. Potato Res. 29 : 95-107.

Manhas, J. S., Sukumaran, N. P. 1988. Diurnal changes in net photosynthetic rate of potato in two environments. Potato Res. 31 : 375-378.

Marinus, J., Bodlaender, K. B. A. 1975. Response of some potato varieties on temperature. Potato Res. 18: $189-204$.

Mattas, R. E., Pauli, A. W. 1965. Trends in nitrate reduction and nitrogen fractions in young corn (Zea 
mays L.) plants during heat and moisture stress. Crop Sci. 5 : 181-184.

Mohabir, G., John, P. 1988. Effect of temperature on starch synthesis in potato tuber tissue and in amyloplasts. Plant Physiol. 88 : 1222-1228.

Moorby, J. 1968. The influence of carbohydrates and mineral nutrient supply on the growth of potato tubers. Ann. Bot. $32: 57-68$.

Onwueme, I. C., Laude, H. M., Huffaker, R. C. 1971. Nitrate reductase activity in relation to heat stress in barley seedlings. Crop Sci. $11: 195-200$.

Petr, J., Cerny, V., Hruska, L. 1988. Yield Formation in the Main Field Crops (Developments in Crop Science, Vol. 13). Elsevier, Amsterdam, pp 336.

Schrader, L. E., Ritenour, G. L., Eilrich, G. L., Hageman, R. H. 1968 . Some characteristics of nitrate reductase from higher plants. Plant Physiol. 43 : 930-940.

Winkler, E. 1971. Potato cultivation in Tyrol. II. Photosynthetic efficiency and respiration in different potato varieties. Potato Res. 14: 1-18.

Wolf, S., Marani, A., Rudich, J. 1990. Effects of temperature and photoperiod on assimilate partitioning in potato plants. Ann. Bot. $66: 513-520$.

Yemm, E. W., Willis, A. J. 1954. The estimation of carbohydrates in plant extracts by anthrone. Biochem. J. 57 : 508-514.

Younis, M. A., Pauli, A. W., Mitchell, H. L., Stickler, F. C. $1965 . \quad$ Temperature and its interaction with light and moisture in nitrogen metabolism of corn (Zea mays L.) seedlings. Crop Sci. 5: 321-326.

\section{〈和文抄録〉}

\section{生育時期別温度処理がパレイショの非構造性炭水化物, 硝酸還元酵素活性ならびに 収量に及ぼす影響}

\section{S. C. ゴシュ・浅沼興一郎・楠谷嘢人・豊田正範}

香川大学農学部

バレイショの生育時期別（I 期：栄養生長期〜塊茎形成期，II期：塊茎形成期〜塊茎肥大初期, III期：塊茎肥大期〜成熟期）に異なる温度処理 $\left(15,25,30^{\circ} \mathrm{C}\right.$ おびガラス室）を行い, 葉の炭水 化物含量, 硝酸還元酵素(NR)活性および収量について調べた. 供試品種はメークイン, 農林 1 号 の 2 品種である.すべての生育時期を通じ, 両品種とも高温は全乾物重, 塊茎乾物重を低下させ, 塊茎の品質(比重)をも低下させた. 葉のN R 活性は高温条件で低くなり低温条件では高くなった. 葉における水溶性炭水化物およびデンプン含量は高温になるほど低くなり, その結果, 全非構造性 炭水化物含量も低くなった. 高温による塊茎収量の抑制は, NR 活性の低下および暗呼吸のための 炭水化物消費に伴い, 塊茎への炭水化物転流が抑制されたことによる.I期における高温条件が最 も収量を低下させ，この時期が最大の危険期と考えられた．また，II期の低温条件によって収量は 最高となり，この時期は収量の向上に対して大きな意義のあることが示唆された。 